УДК 681.513.5

Oleksij Lobok, PhD phys.\&math. Sci., Boris Goncharenko, Prof., DSc.

National University of Food Technologies, Kyiv, Ukraine

Larisa Vihrova, Prof., PhD tech. sci., Central Ukrainian National Technical University,Kropyvnytskyi, Ukraine

Marina Sych, PhD tech. sci.

National University of Bioresources and Natural Resources of Ukraine, Kyiv

\title{
Synthesis of Modal Control of Multidimensional Linear Systems Using Linear Matrix Inequalities
}

The paper gives a solution to the problem of constructing modal regulators for linear multidimensional systems that provide $D$-stability (asymptotic stability) of the control object. The control is represented as regulators providing feedback on the output of the control object, and uses the full and low order observers of Luenberger. To calculate the matrices of the regulators, we use the technique of linear matrix inequalities and generalize the Lyapunov stability concept ( $D$ - stability). The theorems are given which give necessary and sufficient conditions for $D$ - stability of the controlled system.

The constructive solution of the synthesis problem $D$ - stabilizing (modal) regulators according to the measured output of the control object, based on the construction of observers of the state of the object of the complete and reduced order, is given. The solution is based on the use of the theory of linear matrix inequalities (LMI). For numerical simulation of the resulting modal regulators you can use effective methods of convex optimization and corresponding software that is included in a number of application packages, in particular, in the MatLab system. In this paper we describe methods for solving not only the direct problem of modal control, when the choice of parameters of a regulator is ensured by the coincidence of the roots of the characteristic equation of a closed system with a predefined set of complex numbers located on the left side of the complex plane, but also other problems of modal control, in which the requirement the exact placement of the roots in the left integrated half-plane is not superimposed, but only their membership in certain specified areas is required. Such areas, described by a system of linear matrix inequalities (LMI), are called LMI domains. dynamical system, modal control, regulators, D - stability, Luenberger observers, linear matrix inequalities, kroneker product of matrices

А.П. Лобок, канд. физ.-мат. наук, Б.Н. Гончаренко, проф., д-р техн. наук Нацииональный университет пищевых технологий, г.Кииев, Украина

Л.Г. Вихрова, проф., канд. техн. наук

Центральноукраинский национальный технический университет, г.Кропивницикий, Украина

М.А. Сыч, канд. техн. наук

Национальный университет биоресурсов и природопользования Украины, г. Киев, Украина

Синтез модального управления многомерными линейными системами с использованием линейных матричных неравенств

Дается решение задачи построения модальных регуляторов для линейных многомерных систем, обеспечивающих D - устойчивость (асимптотическую устойчивость) объекта управления. Управление представлено в виде регуляторов, обеспечивающих обратную связь по выходу объекта управления, и использует наблюдатели Луенбергера полного и пониженного порядка. Для вычисления матриц регуляторов используется техника линейных матричных неравенств и обобщение понятия устойчивости по Ляпунову (D - устойчивость). Приведенные теоремы дают необходимые и достаточные условия D устойчивости управляемой системы.

В работе дается конструктивное решение задачи синтеза D - стабилизирующих (модальных) регуляторов по измеряемым выходом объекта управления, основанного на построении наблюдателей состояния объекта определенного порядка. Решение получено на основе использования теории линейных матричных неравенств (LMI). Для численного моделирования полученных модальных регуляторов можно использовать методы выпуклой оптимизации и соответствующее программное обеспечение, которое входит в ряд пакетов прикладных программ, в частности, в систему MatLab.

(C) Oleksij Lobok, Boris Goncharenko, Larisa Vihrova, Marina Sych, 2018 
Описаны методы решения не только прямой задачи модального управления, когда выбором параметров регулятора обеспечивается совпадение корней характеристического уравнения замкнутой системы с предварительно заданным набором комплексных чисел, расположенных в левой части комплексной плоскости, но и других задач модального регулирования, в которых требование точного размещения корней в левой комплексной полуплоскости уже не накладывается, а нужна только их принадлежность к некоторым заданным областям, описываемым системой линейных матричных неравенств и называемых LMI- областями.

динамическая система, модальное управление, регуляторы, D - устойчивость, наблюдатели Луенбергера, линейные матричные неравенства, кронекерово произведение матриц

Introduction. Often, in control tasks from the set of stabilization controls, it is necessary to select a subset, which provides for the system additional properties. Such property may be, for example, the location of the roots of the characteristic polynomial of a closed system in a given region of the complex plane. Control having such additional properties is called modal control, and the regulator that provides it is considered modal. Modal control relates to the root methods of linear ACS synthesis, in which, based on the desirable indicators of the quality of control, the desired characteristic polynomial is constructed, and hence the location of the roots of the characteristic equation is determined. Characteristic values of the roots of Latin are called modes, hence the name of the regulator and control - modal.

Formulation of the problem. The following statement of the problem is possible: the choice of control parameters provides for the exact coincidence of the roots of the characteristic equation of a closed system with a predefined set of complex numbers located on the left side (condition of stability) of the complex plane. Such a task is sometimes called the direct task of modal control. In this paper, we describe the following methods for solving other problems of modal regulation, in which the requirement of the exact placement of the roots in the left integrated half-plane is not superimposed, but only their membership in a given domain is required. As noted above, the task of modal control is related to the construction of a regulator, in which the poles of the closed system are located at given points or given areas of the complex plane. The values of such characteristics of a closed system as the transition time, damping, the velocity of transient processes in the regulator, and others are determined by the arrangement of the eigenvalues of the matrix of the closed system in certain areas of the complex plane.

The purpose of the article is to consider the problem of modal control in such areas, which can be described by a system of linear matrix inequalities - these areas will later be called LMI-domains $[1,3,4,5]$. It can be shown that these areas include vertical and horizontal bands, circles, conical sectors, as well as sections of these areas.

Presenting main material. One of the effective methods for solving problems of modulation control synthesis is connected with the use of Lyapunov quadratic functions and the technique of linear matrix inequalities.

The general approach to the modal control synthesis is based on the use of LMI. It turns out that the domains of a certain type on the complex plane in which it is necessary to place the eigenvalues of a matrix of a closed linear system can be described by linear matrix inequalities, that is, as LMI-regions, first recording the necessary inequalities with respect to the variables, and then executing their replacement on some matrices by a special substitution.

In the general case, consider the formal procedure for obtaining linear matrix inequalities that determine the criteria for placing all eigenvalues of the matrix of the control object in the required LMI domain. Note that for numerical solution of the obtained linear matrix inequalities, existing effective algorithms that are implemented in some mathematical packages, in particular MatLab [1.8], can be used. 
In the general case, consider the formal procedure for obtaining linear matrix inequalities that determine the criteria for placing all eigenvalues of the matrix of the control object in the required LMI domain. Note that for numerical solution of the obtained linear matrix inequalities, existing effective algorithms that are implemented in some mathematical packages, in particular MatLab [1.8], can be used.

Let's introduce the concept of LMI-area. Let $D$ be some area of the left integrated halfplane. A dynamical system will be called $D$-stable if all its poles, that is, all the eigenvalues of the matrix, lie in the domain $D$. In this case, the matrix A will also be called $D$-stable. In a particular case, when $D$ coincides with the entire left-most complex half-plane, $D$-stability is reduced to asymptotic stability, which is characterized by the Lyapunov inequality, which is a linear matrix inequality. Namely, the matrix $A$ is asymptotically stable if and only if there exists a symmetric matrix $X$ satisfying the inequalities

$$
A X+X A^{T}<0, \quad X>0
$$

Define a class of domains that are characterized in terms of linear matrix inequalities. To do this, we introduce the matrix functions of the complex variable into consideration $z \in C$ ( $C-$ a set of complex numbers) that take values in the space of self-connected Hermitian $(m \times m)$ - matrices (Hermit Charles, 1822 - 1901)

$$
f_{D}(z)=P+z G+\bar{z} G^{T}
$$

where $P=P^{T} \in R^{m \times m}$ and $G \in R^{m \times m}$ - given matrices ( $R^{m \times m}-$ set of real matrices of dimension $m \times m), \bar{z}-$ combined complex number.

Domain

$$
D=\left\{z \in C: f_{D}(z)<0\right\}
$$

called LMI-domain generated by the function $f_{D}(z)$, which is often called the characteristic function of the domain $D$.

From this definition it follows that the LMI-domain is a subset of a complex plane that is represented by a linear matrix inequality with respect to variables $x=\operatorname{Re}(z)$ and $y=\operatorname{Im}(z)$. Consequently, the LMI-domain is convex. Also, because of any $z \in D$ takes place $f_{D}(\bar{z})=\bar{f}_{D}(z)<0$, then the LMI-domain is symmetric with respect to the actual axis.

The most important property of LMI domains is that they are completely determined in terms of linear matrix inequalities with respect to some symmetric positively defined matrix. In order to get these inequalities, we will match the function $f_{D}(z)$ the next $(m \times m)$ block matrix

$$
M(A, X)=P \otimes X+G \otimes(A X)+G^{T} \otimes\left(X A^{T}\right)
$$

where $" \otimes "$ - the operation of the kroneker product of matrices (Kronecker Leopold, 1823 - 1872).

Recall that the kronecker product matrix is called block matrix, formed by multiplying each element $a_{i j}$ of the matrix $A$ on the matrix $B$ [2]. Given this, note that blocks of the matrix $M(A, X)$ can be written in the form

$$
M_{i j}(A, X)=p_{i j} X+g_{i j} A X+g_{j i} X A^{T}, \quad i, j=1,2, \ldots, m,
$$


where $p_{i j}, g_{i j}$ - the elements of the matrices $P$ and $G$, respectively.

To construct modal regulators that provide the stability of control objects, it is important to prove Theorem 1 of stability [3.5,7].

Let $D$ - LMI-domain. Then the matrix $A$ is $D$ - stable if and only if there is a matrix $X=X^{T}$ which satisfies the linear matrix inequalities

$$
M(A, X)<0, \quad X>0 .
$$

If the matrix (5) is multiplied left and right on the matrix $E \otimes Y$, where $E$ - unit matrix, $Y=X^{-1}$, then taking into account the properties of the operation of the kronecker product after a series of transformations we obtain the criterion $D$ - stability of the matrix $A$

$$
L(A, Y)=P \otimes Y+G \otimes(Y A)+G^{T} \otimes\left(A^{T} Y\right)<0, \quad Y=Y^{T}>0 .
$$

On the basis of Theorem 1 one can propose the following algorithm for constructing LMI - domains that determine the $D$-stability criterion of the system $\dot{x}(t)=A x(t)$ :

1. A characteristic function $f_{D}(z)$ of the form (1) is constructed so that the set $D$ generated by it has the desired form.

2. Using substitution $(1, z, \bar{z}) \leftrightarrow\left(X, A X, X A^{T}\right)$ the function $f_{D}(z)$ of the block matrix $M(A, X)$ of the form (3) are brought into conformity.

3. A system of matrix inequalities of the form (5) (or (6)) is formed and is solved with respect to the matrix $X$ (or $Y$ ).

4. In accordance with the above theorem 1 we conclude that $\mathrm{D}$ is the stability of a multidimensional linear system $\dot{x}(t)=A x(t)$.

Note one important property of the LMI - domains: LMI - the domains are locked in relation to the intersection operation, that is, the intersection of the LMI - the domains will also be LMI- domain.

Consider some important examples of constructing an LMI domain.

As a first example, consider the set $D_{1}=\{z \in C: \operatorname{Re}(z)<-\mu\}$ (Fig.1.a) which corresponds to asymptotically stable systems with a degree of stability no less $\mu$. Obviously, this domain generates a function $f_{D_{1}}(z)=z+\bar{z}+2 \mu$, and according to Theorem 1 , the matrix $A$ is asymptotically stable with a degree of stability not less $\mu$ if and only if there is a matrix $X=X^{T}$, which satisfies the linear matrix inequalities of the form (5)

$$
A X+X A^{T}+2 \mu X<0, \quad X>0 .
$$

Another example of the LMI domain is $D_{2}=\{z \in C:|z+q|<r\}-$ inside the circle with a radius $r$ centered at the point $(-q, 0)$ ( Fig. 1.b). For this domain

$$
f_{D_{2}}(z)=\left(\begin{array}{cc}
-r & q+z \\
q+\bar{z} & -r
\end{array}\right)<0
$$

and the linear matrix inequalities (5) characterizing this region take the form

$$
\left(\begin{array}{cc}
-r X & q X+A X \\
q X+X A^{T} & -r X
\end{array}\right)<0, \quad X>0 .
$$



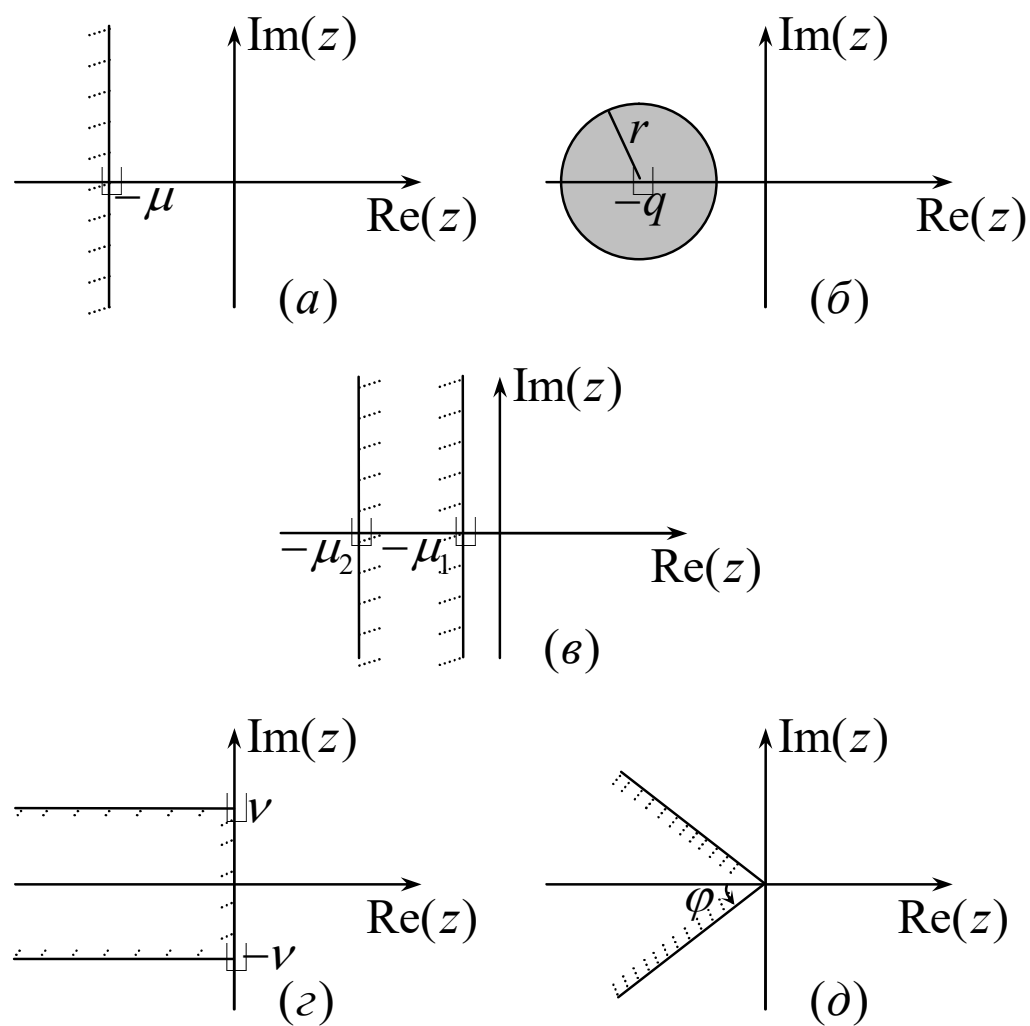

Figure1 - Examples of LMIs are domains of stability

Vertical strip $D_{3}=\left\{z \in C:-\mu_{2}<\operatorname{Re}(z)<-\mu_{1}\right\}$ (Fig.1.c) matches the function

$$
f_{D_{3}}(z)=\left(\begin{array}{cc}
(z+\bar{z})+2 \mu_{1} & 0 \\
0 & -(z+\bar{z})-2 \mu_{2}
\end{array}\right)
$$

and, respectively, linear matrix inequalities

$$
\left(\begin{array}{cc}
A X+X A^{T}+2 \mu_{1} X & 0 \\
0 & -A X-X A^{T}-2 \mu_{2} X
\end{array}\right)<0, \quad X>0 .
$$

Horizontal half- strip $D_{4}=\{z \in C: \operatorname{Re}(z)<0,-v<\operatorname{Im} z<v\}$ (Fig.1.d) corresponds to the characteristic function

$$
f_{D_{4}}(z)=\left(\begin{array}{cc}
-2 v & z-\bar{z} \\
-(z-\bar{z}) & -2 v
\end{array}\right)
$$

and linear matrix inequalities

$$
\left(\begin{array}{cc}
-2 v X & A X-X A^{T} \\
-A X+X A^{T} & -2 v X
\end{array}\right)<0, \quad X>0 .
$$



function

Finally, to the conic sector $\mathrm{D}_{5}=\{\mathrm{z} \in \mathrm{C}: \operatorname{Re}(\mathrm{z}) \operatorname{tg} \varphi<|\operatorname{Imz}|\}$ (Fig.1.e) corresponds the

$$
f_{D_{5}}(z)=\left(\begin{array}{cc}
(z+\bar{z}) \sin \varphi & (z-\bar{z}) \cos \varphi \\
-(z-\bar{z}) \cos \varphi & (z+\bar{z}) \sin \varphi
\end{array}\right)
$$

and linear matrix inequalities

$$
\left(\begin{array}{cc}
\left(A X+X A^{T}\right) \sin \varphi & \left(A X-X A^{T}\right) \cos \varphi \\
-\left(A X-X A^{T}\right) \cos \varphi & \left(A X+X A^{T}\right) \sin \varphi
\end{array}\right)<0, \quad X>0 .
$$

Apply now to the apparatus for synthesizing modal control of the linear system for a given LMI- domain. The classical approach to the synthesis of linear feedback (regulators) in the state space is associated with the canonical representation of the controlled object and the construction of a modal control (controller) that provides the given eigenvalues (mods) of the matrix of a closed system. Then the construction of the modal control reduces to the finding of the characteristic polynomial of the matrix $A$, the choice of the canonical basis, and the solution of the system of linear equations. At the same time, an alternative way of synthesizing stabilizing regulators is possible, based on the application of the theory of linear matrix inequalities and effective algorithms for their solution, implemented, for example, in the MatLab package $[6,8]$.

Let the control object be described by the equation

$$
\frac{d x(t)}{d t}=A x(t)+B u(t)
$$

Where $x(t) \in R^{n}$ - state of the regulator, $u(t) \in R^{m}-$ control.

The task is to choose the law of management $u(t)$ from the class of linear feedback on the state of the form

$$
u(t)=K x(t),
$$

where $K$ - the matrix of the parameters of the regulator corresponding to the order in which the matrix of the closed system (7), (8) will be $D$-stable, that is, all its eigenvalues of the roots lie in the given LMI- domain.

According to Theorem 1, the problem of $D$-stability is reduced to the finding of the matrices $\mathrm{X}=\mathrm{X}^{\mathrm{T}}>0$ and $K$, satisfying inequality $M(A+B K, X)$, which is nonlinear in relation to these matrices. However, if you enter the notation $Z=K X$, then the last inequality can be imagined as a linear matrix inequality of the form

$$
\begin{aligned}
& M(A+B K, X)=P \otimes X+G \otimes((A+B K) X)+G^{T} \otimes\left(X(A+B K)^{T}\right)= \\
& =P \otimes X+G \otimes(A X+B Z)+G^{T} \otimes(A X+B Z)^{T}=P \otimes X+G \otimes(A X)+G \otimes(B Z)+ \\
& +G^{T} \otimes(A X)^{T}+G^{T} \otimes(B Z)^{T}=M(A, X)+G \otimes(B Z)+G^{T} \otimes(B Z)^{T}<0
\end{aligned}
$$

on unknown matrices $K$ and $Z$. After these matrices are found, the desired matrix of the parameters of the regulator is like $K=Z X^{1}$.

Let's consider another approach to the synthesis of $D$-stabilizing regulators based on the measured output, based on the construction of observers of the state of the object. Let's start with Luenberger's observers in complete order.

For a controled object 


$$
\left\{\begin{array}{l}
\dot{x}(t)=A x(t)+B u(t) \\
y(t)=C x(t)
\end{array}\right.
$$

(where $x(t) \in R^{n}$-state of the regulator, $u(t) \in R^{m}$ - control, $y(t) \in R^{p}$ - the measured output of an object) we choose a regulator in the form of an observer of the state of Luenberger of complete order

$$
\left\{\begin{array}{l}
\dot{x}_{r}(t)=A x_{r}(t)+B u(t)+L\left(C x_{r}(t)-y(t)\right), \\
u(t)=K x_{r}(t),
\end{array}\right.
$$

where $x_{r}(t) \in R^{n}$ - state of the regulator.

It is necessary to define matrices and so that the closed system (9), (10) is D-stable.

We introduce the vector of inconsistency $e(t)=x(t)-x_{r}(t)$ and as a state of a closed system we choose a vector $\left(x^{T}(t), e^{T}(t)\right)^{T}$, which satisfies the generalized equation

$$
\frac{d}{d t}\left(\begin{array}{l}
x(t) \\
e(t)
\end{array}\right)=\left(\begin{array}{cc}
A+B K & -B K \\
0 & A+L C
\end{array}\right)\left(\begin{array}{l}
x(t) \\
e(t)
\end{array}\right) .
$$

Obviously, for $D$ - stability of this system, it is necessary and sufficient that the matrices $A+$ $B K$ and $A+L C$ be $D$ - stable. Applying now to the matrix $A+B K$ of Theorem 1, in which the criterion of $D$-stability is given in the language of linear matrix inequalities, we arrive at the following form of LMI

$$
\begin{aligned}
M\left(A+B K, X_{1}\right) & =P \otimes X_{1}+G \otimes\left((A+B K) X_{1}\right)+G^{T} \otimes\left(X_{1}(A+B K)^{T}\right)= \\
& =M\left(A, X_{1}\right)+G \otimes\left(B Z_{1}\right)+G^{T} \otimes\left(Z_{1}^{T} B^{T}\right)<0,
\end{aligned}
$$

where $Z_{1}=K X_{1}$

Applying to the matrix criterion D - stability in the form of inequality (6), we obtain another LMI

$$
\begin{aligned}
L\left(A+L C, X_{2}\right) & =P \otimes X_{2}+G \otimes\left(X_{2}(A+L C)\right)+G^{T} \otimes\left((A+L C)^{T} X_{2}\right)= \\
& =L\left(A, X_{2}\right)+G \otimes\left(Z_{2} C\right)+G^{T} \otimes\left(C^{T} Z_{2}^{T}\right)<0,
\end{aligned}
$$

where $Z_{2}=X_{2} L$.

Thus, we arrive at the necessity of derivation of Theorem 2 .

It is necessary and sufficient that the linear matrix inequalities (11) and (12) be solved with respect to the variables in order for the object (9) to be D-stabilized by means of the controller at the output of the form (10) $X_{1}=X_{1}^{T}>0, Z_{1}$ and $X_{2}=X_{2}^{T}>0, Z_{2}$. In the case of the possibility of solving these inequalities, the parameters of the regulator are as follows

$$
K=Z_{1} X_{1}^{-1}, \quad L=X_{2}^{-1} Z_{2} \text {. }
$$

We now synthesize a regulator based on the Luangenberger observer of incomplete order [1,5]. Suppose that in the control object (9) the rank of the matrix $C$ is $(p<n)$. Consider an observer

$$
\frac{d z(t)}{d t}=F z(t)+T B u(t)+Q y(t)
$$


where $z(t) \in R^{l}, l=n-p$-observer state, $y(t)$ and $u(t)-$ the measured output and control in the object (9), and the matrices $F, T$ and $Q$ satisfy the matrix equation

$$
T A-F T=Q C \text {. }
$$

Re-enter the vector of inconsistency $e(t)=z(t)-T x(t)$ and note that due to the equations of the object and the observer for him equality is fulfilled

$$
\frac{d e(t)}{d t}=F e(t) \text {. }
$$

Thus, if the matrix $F$ is a $D$-stable, then the vector $z(t)$ asymptotically tracks the vector $T x(t)$ and in combination with the vector $y(t)$ gives an estimate of the state vector of the object.

To simplify, but not diminishing the generality, we will accept $C=\left(E_{p} 0_{p^{\star}}\right)$, where $E_{p}-$ unit matrix of dimension $p$. Note that this can be achieved by replacing the variables accordingly. We break the matrix $A$ and $B$ into blocks

$$
A=\left(\begin{array}{ll}
A_{11} & A_{12} \\
A_{21} & A_{22}
\end{array}\right), \quad B=\left(\begin{array}{c}
B_{1} \\
B_{2}
\end{array}\right),
$$

в яких $A_{11} \in R^{p^{\times p}}, B_{1} \in R^{p^{\times} m-}$ (the orders of other blocks are determined in an obvious manner).

Choose the matrices $F, T$, and $Q$, which satisfy the equation (14), in the following way

$$
F=A_{22}+L A_{12}, \quad T=\left(\begin{array}{ll}
L & E_{l}
\end{array}\right), \quad Q=A_{21}+L A_{11}-\left(A_{22}+L A_{12}\right) L,
$$

where the matrix $L$ should be determined from the condition that the matrix $F$ be $D$-stable.

In accordance with the chosen choice, we introduce the equation of the regulator (control) in the

$$
\begin{gathered}
\text { form } \frac{d x_{r}(t)}{d t}=\left(A_{22}+L A_{12}\right) x_{r}(t)+\left(B_{2}+L B_{1}\right) u(t)+\left[A_{21}+L A_{11}-\left(A_{22}+L A_{12}\right) L\right] y(t), \\
u(t)=K_{1} x_{r}(t)+K_{2} y(t),
\end{gathered}
$$

where the matrices $K_{1}$ and $K_{2}$ must be determined from the condition of the $D$-stability of the closed system (9), (16). Substituting the equation of control into the output system and taking into account that $x_{r}(t)=\operatorname{Tx}(t)+e(t)$, we will get

$$
\left\{\begin{array}{l}
\frac{d x(t)}{d t}=(A+B K) x(t)-B K_{1} e(t), \\
\frac{d e(t)}{d t}=F e(t),
\end{array}\right.
$$

where $K=\left(\begin{array}{ll}K_{2}+K_{1} L & K_{1}\end{array}\right)$.

Thus, the matrix $K$ is based on the condition that the matrix $A+B K$ is $D$-stable, and then, taking into account the already found matrix $L$, the matrices of the regulator $K_{1}$ and $K_{2}$ are determined. Applying now Theorem 1 and the technique of derivation of Theorem 2, we arrive at the following theorem 3 .

In order for an object described by system (9) to be $D$-stabilized by means of a regulator on the output of the reduced order of form (16), it is necessary and sufficient that the linear matrix inequalities

$$
\begin{gathered}
M\left(A+B K, X_{1}\right)=M\left(A, X_{1}\right)+G \otimes\left(B Z_{1}\right)+G^{T} \otimes\left(Z_{1}^{T} B^{T}\right)<0, \\
L\left(A_{22}+L A_{12}, X_{2}\right)=L\left(A_{22}, X_{2}\right)+G \otimes\left(Z_{2} A_{12}\right)+G^{T} \otimes\left(A_{12}^{T} Z_{2}^{T}\right)<0
\end{gathered}
$$


were solved with respect to matrix variables $X_{1}=X_{1}^{T}>0, Z_{1}$ and $X_{2}=X_{2}^{T}>0, Z_{2}$, where the matrix $M\left(A, X_{1}\right)$ and $L\left(A_{22}, X_{2}\right)$ are determined by formulas (3) and (6) respectively. In the case of the possibility of solving these inequalities, the parameters of the regulator are as follows

where

$$
K_{1}=H_{2}, \quad K_{2}=H_{1}-H_{2} L
$$

$$
H=\left(\begin{array}{ll}
H_{1} & H_{2}
\end{array}\right)=Z_{1} X_{1}^{-1}, \quad H_{1} \in R^{m \times p}, H_{2} \in R^{m \times l}, \quad L=X_{2}^{-1} Z_{2} .
$$

Conclusion. Thus, the use of the Luenberger observers allows for the synthesis of $D$ stable regulators for the complete and reduced order of the Leuvenberger observers on the basis of solving only linear matrix inequalities.

\section{Reference}

1. Баландин Д.В. Синтез законов управления на основе линейных матричных неравенств [Текст] / Д.В.Баландин, М.М. Коган //- М.: Физматлит, 2007. - 281 с.

2. $\quad$ Гантмахер Ф.Р. Теория матриц [Текст] / Ф.Р. Гантмахер. - М.: Физматлит, 2004. - 560 с.

3. Поляк Б.Т. Управление линейными системами при внешних возмущениях: Техника линейных матричных неравенств [Текст] / Б.Т.Поляк,М.В. Хлебников. - М.: ЛЕНАНД, 2014. - 560 с.

4. Якубович В.А. Решение некоторых матричных неравенств, встречающихся в теории автоматического регулирования [Текст] / В.А. Якубович // ДАН СССР. - 1962. - Т. 143. - №6. C. 1304-1307.

5. Boyd S., El Ghaoui L., Feron E., Balakrishnan V. LinearMatrix Inequalities in System and Control Theory [Text] / S. Boyd, El L.Ghaoui, E. Feron, V. Balakrishnan. - Philadelphia: SIAM, 1994, 193 p.

6. Chilali M. $H^{\infty}$ design with pole placement constraints: An LMI approach. IEEE Trans. [Text] / M.Chilali, P. Gahinet. - Automat. Contr., 1996, vol.41, pp. 358-367.

7. Ghaoui L.E. Advances in linear matrix inequality methods in control. Advances in Design and Control. [Text] / L.E.Ghaoui, S.I. Niculescu. - Philadelphia, PA: SIAM, 2000, 372 p.

8. Masubuchi I., Ohara A., Suda N. LMI-based controller synthesis: A unified formulation and solution. [Text] / I. Masubuchi, A. Ohara, N. Suda . -Int. J. Robust Nonlinear Contr., 1998, vol. 8, pp. 669-686.

\section{Reference}

1. Balandin, D.V. \& Kogan, M.M. (2007). Sintez zakonov upravlenija na osnove linejnyh matrichnyh neravenstv [Synthesis of control laws based on linear matrix inequalities]. Moscow: Fizmatlit.

2. Gantmaher, F.R. (2004). Teorija matric [Теория матриц]. Moscow: Fizmatlit.

3. Poljak, B.T. \& Hlebnikov, M.V. (2014). Upravlenie linejnymi sistemami pri vneshnih vozmushhenijah: Tehnika linejnyh matrichnyh neravenstv [Control of linear systems under external disturbances: Technique of linear matrix inequalities]. Moscow: LENAND.

4. Jakubovich, V.A. (1962). Reshenie nekotoryh matrichnyh neravenstv, vstrechajushhihsja v teorii avtomaticheskogo regulirovanija [The solution of some matrix inequalities encountered in the theory of automatic regulation]. DAN SSSR - DAN SSSU, Vol. 143, 6, 1304-1307.

5. Boyd, S., El Ghaoui, L., Feron, E. \& Balakrishnan, V. (1994). LinearMatrix Inequalities in System and Control. Philadelphia: SIAM.

6. Chilali, M. \& Gahinet, P. (1996). $H^{\infty}$ design with pole placement constraints: An LMI approach. IEEE Trans. Automat. Contr., vol.41, 358-367.

7. Ghaoui, L.E. \& Niculescu, S.I. (2000). Advances in linear matrix inequality methods in control. Advances in Design and Control. PA: SIAM.

8. Masubuchi, I., Ohara, A. \& Suda, N. (1998). LMI-based controller synthesis: A unified formulation and solution. Int. J. Robust Nonlinear Contr., Vol. 8, 669-686.

А.П. Лобок, канд. фіз.-мат. наук, Б.Н. Гончаренко, проф., д-р техн. наук

Національний університет харчових технологій, м.Київ, Украӥна

Л.Г. Віхрова, проф., канд. техн. наук

Центральноукраӥнський наџіональний технічний університет, м.Кропивницький, Украӥна

М.А. Сич, канд. техн. наук 
Наиіональний університет біоресурсів і природокористування України, м.Київ, Украӥна

\section{Синтез модального керування багатовимірними лінійними системами 3 використанням лінійних матричних нерівностей}

Дається розв'язок задачі побудови модальних регуляторів для лінійних багатовимірних систем, що забезпечують $D$ - стійкість (асимптотичну стійкість) об'єкта керування. Керування представлено у вигляді регуляторів, що забезпечують зворотний зв'язок за виходом об'єкта керування, і використовує спостерігачі Луенбергера повного i зниженого порядку. Для обчислення матриць регуляторів використовується техніка лінійних матричних нерівностей $\mathrm{i}$ узагальнення поняття стійкості за Ляпуновим ( $D$ - стійкість). Наведені теореми, що дають необхідні і достатні умови $D$ - стійкості керованої системи.

В роботі дається конструктивний розв'язок задачі синтезу D - стабілізувальних (модальних) регуляторів за вимірюваним виходом об'єкта керування, заснований на побудові спостерігачів стану об'єкта певного порядку. Розв'язок отримано на основі використання теорії лінійних матричних нерівностей (LMI). Для чисельного моделювання отриманих модальних регуляторів можна використовувати ефективні методи опуклої оптимізації і відповідне програмне забезпечення, яке входить до ряду пакетів прикладних програм, зокрема, в систему MatLab.

Описуються методи розв'язання не тільки прямої задачі модального керування, коли вибором параметрів регулятора забезпечується збіг коренів характеристичного рівняння замкненої системи 3 попередньо заданим набором комплексних чисел, розташованих в лівій частині комплексної площини, але i інших задач модального регулювання, в яких вимога точного розміщення коренів в лівій комплексної півплощині вже не накладається, а потрібна лише їх приналежність до деяких заданих областей. Такі області, описані системою лінійних матричних нерівностей, називаються LMIобластями.

динамічна система, модальне керування, регулятори, $D$ - стійкість, спостерігачі Луенбергера, лінійні матричні нерівності, кронекеровий добуток матриць

Одержано (Received) 19.04.2018

\section{УДК 681.536.54}

Д.М. Лужков, асп., С.І. Осадчий, проф., д-р техн. наук, О.К. Дідик, доц., канд. техн. наук

Центральноукраӥнський національний технічний університет, м. Кропивницький, Україна,E-mail:srg2005@ukr.net

\section{Ідентифікація лінеаризованої моделі динаміки контролера та терморегулювального вентилю фірми Danfoss за даними пасивного експерименту}

Мета статті полягає у забезпеченні конструкторів та дослідників роботи систем автоматизації процесу керування холодильним обладнанням 3 одним терморегулювальним вентилем вихідними даними про лінеаризовану модель динаміки контролера разом з регулювальним органом. Ідентифікація виконана у три етапи. На першому етапі на основі даних пасивного експерименту одержані спектральні та взаємні спектральні щільності сигналів. На другому етапі, на основі результатів першого, визначені передаточні функції елементів системи та формуючого фільтру завад. На третьому етапі виконана верифікація результатів ідентифікації, при якій використовувались експериментальні дані та одержані передаточні функції на другому етапі.

хладагент, випарник, структурна схема, вектор, збурення, регулятор

(ㄱ Д.М. Лужков, С.І. Осадчий, О.К. Дідик, 2018 